University of Nebraska - Lincoln

DigitalCommons@University of Nebraska - Lincoln

\title{
LLWR Techniques for Quantifying Potential Soil Compaction Consequences of Crop Residue Removal
}

Joseph G. Benjamin

USDA-ARS, Joseph.Benjamin@ars.usda.gov

Douglas Karlen

USDA-ARS, doug.karlen@ars.usda.gov

Follow this and additional works at: https://digitalcommons.unl.edu/usdaarsfacpub

Benjamin, Joseph G. and Karlen, Douglas, "LLWR Techniques for Quantifying Potential Soil Compaction Consequences of Crop Residue Removal" (2014). Publications from USDA-ARS / UNL Faculty. 1641. https://digitalcommons.unl.edu/usdaarsfacpub/1641

This Article is brought to you for free and open access by the U.S. Department of Agriculture: Agricultural Research Service, Lincoln, Nebraska at DigitalCommons@University of Nebraska - Lincoln. It has been accepted for inclusion in Publications from USDA-ARS / UNL Faculty by an authorized administrator of DigitalCommons@University of Nebraska - Lincoln. 


\title{
LLWR Techniques for Quantifying Potential Soil Compaction Consequences of Crop Residue Removal
}

\author{
Joseph G. Benjamin • Douglas L. Karlen
}

Published online: 9 January 2014

(C) Springer Science+Business Media New York (outside the USA) 2014

\begin{abstract}
Harvesting crop residues for bioenergy or bioproduct production may decrease soil organic matter (SOM) content, resulting in the degradation of soil physical properties and ultimately soil productivity. Using the least limiting water range (LLWR) to evaluate improvement or degradation of soil physical properties in response to SOM changes has generally been hampered by the extensive amount of data needed to parameterize limiting factor models for crop production. Our objective was to evaluate five pedotransfer functions to determine their effectiveness in predicting soil water holding capacity in response to different SOM levels. Similarly, two other pedotransfer functions were evaluated to determine the effects of SOM on cone index values. Predictions of field capacity and wilting point water content as well as the cone index-water content-bulk density relationship of soil strength using the pedotransfer functions were compared with field data from two tillage experiments near Akron, CO that had a range of SOM concentrations. Equations previously developed by da Silva and Kay gave the best estimates of LLWR for the pedotransfer functions we evaluated. These equations were then used to illustrate LLWR changes in response to different soil and crop management practices on a Duroc loam near Sidney, NE. The results showed that tillage and, possibly, soil erosion decreased the LLWR as tillage intensity increased. Therefore, we recommend that crop residue removal rates be limited to rates that maintain or increase SOM content to ensure soil physical conditions are not degraded.
\end{abstract}

\footnotetext{
J. G. Benjamin $(\bowtie)$

Agricultural Research Service (ARS), Central Great Plains Research Station, USDA, 40335 County Road GG, Akron, CO 80720, USA

e-mail: Joseph.Benjamin@ars.usda.gov

D. L. Karlen

Agricultural Research Service (ARS), National Laboratory for Agriculture and the Environment (NLAE), USDA, 2110 University Boulevard, Ames, IA 50011, USA
}

This document is a U.S. government work and is not subject to copyright in the United States.

Keywords Least limiting water range $\cdot$ LLWR $\cdot$ Crop residue removal $\cdot$ Soil quality $\cdot$ Soil physical properties

\section{Introduction}

The projected shortage of fossil fuels over the next 50 years, national security issues associated with ensuring adequate petroleum supplies, and recent increases in energy prices [1] have renewed interest in replacing a portion of the fossil fuel energy used in the USA with advanced biofuels developed using cellulose, hemicelluloses, or lignin feedstocks. Crop residues, the portion of plants that remain after harvesting grain from many agricultural crops, are a potential source for cellulosic feedstock. The amounts of crop residue and other feedstock sources including perennial grasses, forest residues, municipal and industrial wastes, and waste products from agricultural processing are large $[2,3]$. As a result, Kim and Dale [4] estimated that potential global bioethanol production could replace up to $33 \%$ of global gasoline consumption. Corn (Zea mays L.) stover has been proposed as a primary feedstock for biofuel production in North America, potentially providing $38.4 \mathrm{GL} \mathrm{year}^{-1}$ of ethanol.

Harvesting crop residues for energy production or any other use can lead to decreases in SOM or soil organic carbon (SOC) content. Decreasing SOC levels can result in degradation of soil physical, chemical, and biological properties. Lal [5] discouraged the use of crop residues for energy production. He cites several reasons to return crop residues to the field including (a) recycling plant nutrients, (b) carbon sequestration, (c) improving soil physical properties such as soil structure and water retention and transmission, (d) enhancing soil fauna, (e) improving water infiltration, (f) controlling water runoff, $(\mathrm{g})$ conserving water in the root zone, and $(\mathrm{h})$ sustaining agronomic productivity.

Several soil physical properties are improved as SOC increases; therefore, balancing the use of crop residues between ecosystem services and bioenergy or bio-product production 
is a critical area of research [6]. For example, Blanco-Canqui and Lal [7] showed a decrease in soil aggregate stability, aggregate strength, and subcritical water repellency with corn stover removal rates as low as $25 \%$. On the other hand, Bauer and Black [8] measured no significant soil bulk density differences at depths ranging from the surface to $450 \mathrm{~mm}$ between cropped and grassland soils due to tillage and crop removal.

The effectiveness of increasing SOM by changing cropping and tillage systems varies considerably among different regions in the USA. A regional study in Indiana, Ohio, and Pennsylvania tested the hypothesis that no-till cropping systems would be more effective for sequestering SOC than conventionally tilled systems, but was inconclusive [9]. In some soils, more SOC was found with no-till (NT) systems, and in others, more SOC was found with conventional tillage. Neither system provided any apparent reason for the unexpected discrepancy. Under dryland conditions in the US central Great Plains, increasing cropping intensity to more than the every-other-year crop production of the traditional wheatfallow system has been shown to increase SOC stocks due to increased residue inputs [10]. Therefore, it is often expected that with irrigation, an even greater increase in SOC could be attained because of the greater productivity than for dryland systems in this region. However, a recent study on soil carbon dynamics for irrigated corn [11] showed a low potential to sequester SOC in the central Great Plains, especially with conventional tillage practices.

\section{Residue Removal Rates}

Residue production varies considerably between crop species and growing environments. Linden et al. [12] showed that continuous corn produced between 4.0 and $5.8 \mathrm{Mg} \mathrm{ha}^{-1}$ year $^{-1}$ crop residue in a continuous corn system in southeastern Minnesota. Benjamin et al. [13] reported crop residue production in an irrigated system in a semiarid environment varied from a high of $7 \mathrm{Mg} \mathrm{ha}^{-1}$ year $^{-1}$ total $\mathrm{C}$ for continuous corn production to a low of $0.7 \mathrm{Mg} \mathrm{ha}^{-1}$ year $^{-1}$ total $\mathrm{C}$ for field pea (Pisum sativum L.). Clearly, corn has the greatest potential of annual grain crops for supplying crop residue for off-farm use.

Various studies have estimated the amount of crop residue that can be removed without affecting SOC levels. Allowable residue removal rates vary depending upon the tillage practice (no tillage vs. tilled), crop species (high $\mathrm{C} / \mathrm{N}$ ratio residue vs. low $\mathrm{C} / \mathrm{N}$ ratio residue), and climate (humid vs. semiarid environments). Wilhelm et al. [14] estimated that 7.6 $\mathrm{Mg} \mathrm{ha}^{-1}$ year $^{-1}$ of crop residue was needed to maintain SOC levels for a continuous corn, moldboard plow system, while $5.2 \mathrm{Mg} \mathrm{ha}^{-1}$ year $^{-1}$ of crop residue was needed to maintain SOC levels for continuous corn, no-till systems.
Benjamin et al. [13] showed that 4.6 to $7.4 \mathrm{Mg} \mathrm{ha}^{-1}$ year $^{-1}$ of total $\mathrm{C}$ from plant residue and roots were needed to maintain SOC for no-till and chisel plow systems, respectively, within an irrigated, semiarid environment. Larson et al. [15] determined that $6 \mathrm{Mg} \mathrm{ha}^{-1}$ year $^{-1}$ crop residue addition (3.5 $\mathrm{Mg} \mathrm{ha}^{-1}$ year $^{-1} \mathrm{C}$ ) was needed to maintain SOC levels in southern Iowa. Pikul et al. [16] determined that $7.4 \mathrm{Mg} \mathrm{ha}^{-1}$ year ${ }^{-1}$ crop residue addition (4.3 $\mathrm{Mg} \mathrm{ha}^{-1}$ year $^{-1} \mathrm{C}$ ) was needed to maintain SOC levels in eastern South Dakota.

If less than adequate amounts of crop residue are returned to the soil, a decrease in SOC would be expected. Decreasing SOC may result in poorer soil conditions and, in the long term, reduce soil productivity. Less favorable soil conditions caused by the decrease in SOC are often reflected by changes in soil characteristics that affect plant growth. This includes factors such as surface crusting, water holding capacity and soil strength, as well as an increased susceptibility of the soil to compactive forces that generally result in increased bulk density $\left(\rho_{\mathrm{b}}\right)$ [17]. Therefore, the effects of residue removal on long-term soil productivity must be considered in any economic analysis of off-farm benefits of using crop residues for other purposes.

\section{Least Limiting Water Range}

Many soil physical conditions have the potential to limit crop production. For example, the soil's ability to store water provides a reservoir for plants to draw upon between rainfall or irrigation events. Soil strength provides anchoring for plants growing in the soil, but too much soil strength can impede root development and limit exploitation of the soil profile for water or nutrients needed by the plant. Terrestrial plants require oxygen in the root zone for proper root function, including water and nutrient uptake. Root growth and exploration, nutrient and water uptake, and the soil resource condition all interact to determine the most limiting factors affecting crop production. A method called the least limiting water range (LLWR) has been developed to account for each of these limiting soil physical conditions and provides a method for evaluating changes in potential soil productivity caused by compaction [18-20].

The LLWR can be used to evaluate improvement or degradation of soil physical properties. A wider LLWR, at a specific bulk density, generally will be less restrictive to plant growth. However, as long as the water content of a soil can be controlled to lie within the LLWR, no productivity restrictions are anticipated.

To construct the LLWR for a particular soil, knowledge of field capacity $\left(\theta_{\mathrm{f}}\right)$, wilting point $\left(\theta_{\mathrm{w}}\right)$, air-filled porosity $\left(\varphi_{\mathrm{a}}\right)$, and the relationship between soil strength, as measured by cone index $(\mathrm{CI}), \rho_{\mathrm{b}}$, and water content $(\theta)$, is needed for the 
range of bulk densities likely to occur in the field. da Silva et al. [19], Betz et al. [21], and Benjamin et al. [20] have defined the limiting $\theta_{\mathrm{f}}$ as the $\theta$ at either -10 or $-33 \mathrm{kPa}$ water potential, the limiting $\theta_{\mathrm{w}}$ as the $\theta$ at $-1,500 \mathrm{kPa}$ water potential, the limiting $\varphi_{\mathrm{a}}$ as $10 \%$ air-filled porosity, and the limiting $\mathrm{CI}$ as $2 \mathrm{MPa}$ cone penetrometer resistance. The LLWR will vary as soil properties, including texture or organic matter, change. Such variations can be expected for different soil types as well as within the profile depth of a specific soil. An example of LLWR variation with soil depth for a Weld loam [20] is shown in Fig. 1.

\section{Pedotransfer Functions for Determining LLWR}

Decreasing SOC caused by excessive removal of plant residues, tillage, or any other factor affects all of the soil physical properties that determine the LLWR. Therefore, to use LLWR to quantify effects of various soil management practices, a large amount of data must be collected for every site or suitable methods for estimating the parameters must be developed. To reduce the data requirements, several researchers have developed pedotransfer functions designed to quantify changes in soil water content and soil strength in response to SOC changes. Pedotransfer functions are mathematical expressions relating different soil characteristics and properties to one another or to land qualities [22] and can be used to calculate complicated soil parameters from simple characteristics [23].

\section{Plant Available Water}

Plant available water is defined as the difference between the soil water content when free drainage $\left(\theta_{\mathrm{f}}\right)$ ceases and the level when essentially no water can be extracted by plants $\left(\theta_{\mathrm{w}}\right)$. The best method to define those water contents is with field measurements, but field methods can be imprecise. Soil heterogeneity complicates the determination of a single value for $\theta_{\mathrm{f}}$ or $\theta_{\mathrm{w}}$ within a given soil or even a single soil horizon. There are problems with determining when free drainage has ceased for determining $\theta_{\mathrm{f}}$ due to the slowness of drainage, particularly with fine-textured soils. Evaporation and plant water use also complicate field measurements of $\theta_{\mathrm{f}}$. Similarly, the point at which no more plant extractable water occurs (i.e., $\theta_{\mathrm{w}}$ ) varies with soil type and especially with plant species.

Commonly, $\theta_{\mathrm{f}}$ and $\theta_{\mathrm{w}}$ are estimated using undisturbed cores and pressure plate desorption equipment. These methods, while imperfect, allow effects of soil management practices on water retention to be compared at consistent and reproducible soil water pressure potentials. The use of undisturbed cores allows for the effects of soil management on soil structure and the effects of structure on soil water holding characteristics to be quantified, provided the assumption that the cores are representative of the whole soil is valid. Unfortunately, these laboratory methods are also time consuming and relatively expensive with regard to both labor and equipment.
Fig. 1 Variation in least limiting water range (LLWR) as affected by profile depth within a Weld loam near Akron, CO (Taken from Benjamin et al. [20])
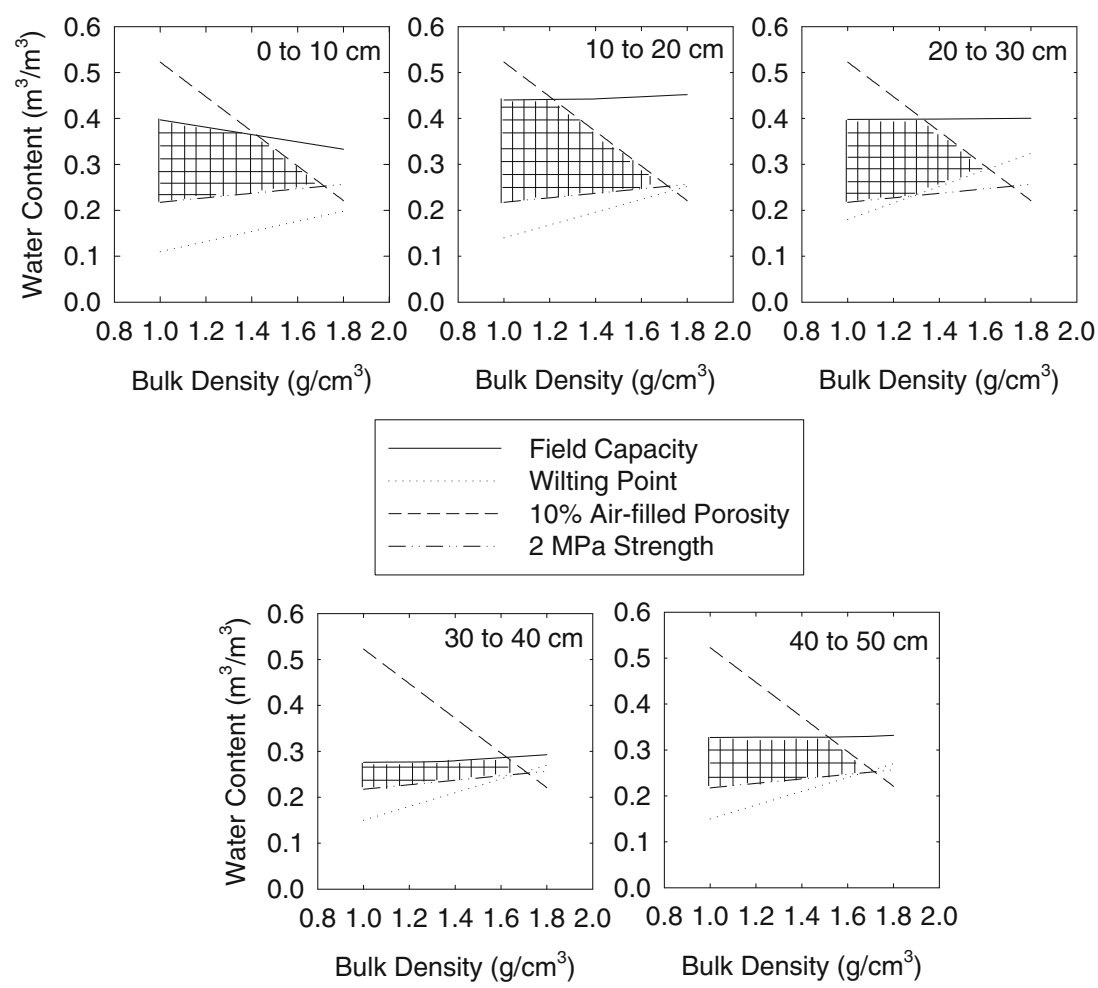
Other researchers have also attempted to develop pedotransfer functions to account for other soil property changes in response to SOM. For example, Gupta and Larson [24] presented a regression model based on particle size analysis, organic matter content, and bulk density that estimates soil water content at various pressure potentials. The model has the form

$\theta_{\mathrm{p}}=a \mathrm{sa}+b \mathrm{si}+c \mathrm{cl}+d \mathrm{OM}+e \rho_{\mathrm{b}}$

where $\theta_{\mathrm{p}}$ is the predicted water content (in cubic centimeter per cubic centimeter) for a given matric potential $(p)$, sa is the sand content (in percent), si is the silt content (in percent), $\mathrm{cl}$ is the clay content (in percent), OM is the organic matter content (in percent), $\rho_{\mathrm{b}}$ is the bulk density (in grams per cubic centimeter), and $a, b, c, d$, and $e$ are regression coefficients. The regression coefficients were determined for individual soil water potentials. The measured water retention characteristics were derived from artificially packed soil cores for 43 soil materials. These equations gave reasonable estimations of water content for soils and soil materials from South Carolina and Missouri.

Rawls et al. [25] developed an equation similar to that of Gupta and Larson [24], but it was based on a different, more extensive data set consisting of field soil samples. Their general equation was:

$\theta_{\mathrm{p}}=a \mathrm{sa}+b \mathrm{si}+c \mathrm{cl}+d \mathrm{OM}+e \rho_{\mathrm{b}}+f \theta_{0.33}+g \theta_{15}$

It included the terms $\theta_{0.33}$ and $\theta_{15}$ which indicate known water contents (in cubic centimeters per cubic centimeter) at -0.33 and -15 bar, respectively. These terms improved the regression correlations, but having to measure those specific parameters defeats the purpose of predicting soil water retention properties using only basic soil information. For comparisons among the water content models evaluated in this report, those terms are ignored.

Ritchie et al. [26] presented a simple method to determine the drained upper limit (often referred to as $\theta_{\mathrm{f}}$ ) of medium textured soils and a method to adjust the values for soils with higher sand content, more coarse fragments, or differences due to SOM changes. The basic equation for determining the drained upper limit gravimetric water content, $w_{\mathrm{d}}$ (in grams per gram), is as follows:

$w_{\mathrm{d}}=a(\text { sand } / \text { clay })^{b}$

where $w_{\mathrm{d}}$ predictions are based on the sand/clay ratio (in percent) and gravimetric water content is converted to volumetric water content at the drained upper $\left(\theta_{\mathrm{d}}\right)$ limit by:

$\theta_{\mathrm{d}}=w_{\mathrm{d}} \rho_{\mathrm{b}} / \rho_{\mathrm{w}}$

where $\rho_{\mathrm{w}}$ is the density of water. Ritchie et al. [26] also assumed that plant extractable water $\left(\theta_{\mathrm{p}}\right)$ is relatively constant, except for soils with high sand content. Therefore, they adjust $\theta_{\mathrm{p}}$ by:

$\theta_{\mathrm{p}}=\theta_{\mathrm{pm}}-a e^{b \text { sand }}$

where $\theta_{\mathrm{pm}}$ is the mean plant extractable water (in cubic meters per cubic meter), sand (expressed in percent), and $a$ and $b$ are regression coefficients. The lower limit $\left(\theta_{1}\right)$ is then calculated as the difference between $\theta_{\mathrm{d}}$ and $\theta_{\mathrm{p}}$ as:

$\theta_{1}=\theta_{\mathrm{d}}-\theta_{\mathrm{p}}$

Ohu et al. [27] presented an empirical model to relate water retention characteristics to several basic soil properties. The major conceptual difference between this model and that of Gupta and Larson [24] is the method used to introduce texture effects on soil water content. While Gupta and Larson [24] simply used percentages of sand, silt, and clay as regression variables, the Ohu model [27] used the liquid limit (LL) as a regression variable to account for changes in clay content and mineralogy. In essence, the equation

$\theta=a \psi^{-n}$

was used, where $\theta$ is the volumetric water content (in cubic centimeters per cubic centimeter), $\psi$ is the soil water pressure potential (in kilopascal), and $a$ and $n$ are empirical coefficients to be determined. They used soils with sandy loam, clay loam, and clay textures along with additions of dried peat moss to attain 30,100 , and $170 \mathrm{~g} \mathrm{~kg}^{-1}$ (3,10, and $17 \%$ ) organic matter. The soils were then compressed at different Proctor compaction levels to attain a variety of bulk densities. Water desorption coefficients were determined from these soil cores as:

$$
\begin{aligned}
a=23.7+ & 0.926 \mathrm{LL}-0.181 \rho_{\mathrm{b}} \times \mathrm{LL} \\
n=-0.428 & +0.016 \mathrm{OM}+0.159 \rho_{\mathrm{b}}+0.000006 \mathrm{CL} \times \mathrm{LL} \\
& +0.0033 \rho_{\mathrm{b}} \times \mathrm{LL}-0.00036 \rho_{\mathrm{b}} \times \mathrm{OM} \\
& \times \mathrm{LL}-0.0000054 \mathrm{CL} \times \rho_{\mathrm{b}} \times \mathrm{LL}
\end{aligned}
$$

The $a$ and $n$ coefficients were determined from the desorption data. The significant correlation factors were $\rho_{\mathrm{b}}$, LL, compaction level (CL), and OM level. Among the significant correlation factors, LL is not routinely determined because, although it is a straightforward procedure, it is still very timeconsuming measurement, using either a Casagrande device or a drop cone device [28].

In lieu of measuring LL, Seybold et al. [29] derived linear regression equations for LL using percentage total clay, percentage organic carbon, water content at $-1,500 \mathrm{kPa}$ soil water potential, cation exchange capacity, percentage linear extensibility, and bulk density as regression factors. The factors used to provide the "best fit" regression model depended upon taxonomic soil order. The coefficient of determination $\left(R^{2}\right)$ for these equations varied between 0.63 and 0.81 . De Jong et al. 
[30] measured the Atterberg limits on a number of soils from Saskatchewan and determined that LL is correlated to the clay and organic matter content within the soil. The regression coefficients were in the range of 0.5 for clay and organic matter in the A horizon and approximately 0.8 for clay in the $\mathrm{B}$ and $\mathrm{C}$ horizons. If LL information is lacking, the coefficients given in these papers could provide an estimate of the liquid limit.

da Silva and Kay [31] specifically attempted to estimate LLWR parameters from basic soil data. They used an equation similar to Eq. 7 of Ohu et al. [27] but derived their coefficients based on clay, organic carbon (OC), $\rho_{\mathrm{b}}$, and logarithmic functions of those variables using multiple regression. Their final equation was as follows:

$$
\begin{aligned}
\ln \theta & =a_{0}+a_{1} \ln \text { clay }+a_{2} \ln \mathrm{OC}+a_{3} \ln \rho_{\mathrm{b}} \\
& +\left(b_{0}+b_{1} \ln \text { clay }+b_{2} \ln \mathrm{OC}+b_{3} \ln \rho_{\mathrm{b}}\right) \ln \psi
\end{aligned}
$$

\section{Aeration}

Root growth due to aeration is a combination of the oxygen $\left(\mathrm{O}_{2}\right)$ status of the soil and plant response to $\mathrm{O}_{2}$ deprivation. Determining root restrictions caused by aeration is a fairly straightforward calculation based on air-filled porosity in the soil at a specific bulk density and water content. The air-filled porosity $\left(\varphi_{\mathrm{a}}\right.$, in cubic meters per cubic meter) is determined as:

$\varphi_{\mathrm{a}}=1-\rho_{\mathrm{b}} / \rho_{\mathrm{p}}-\theta$

where $\rho_{\mathrm{p}}$ is the mean soil particle density, and $\theta$ is the soil volumetric water content.

As noted by da Silva et al. [19], soil water content in excess of field capacity by itself does not limit plant growth. Growth is only limited when soil water content increases to the point that limited aeration exists. Two important levels of soil aeration have been identified. Grable and Siemer [32] showed that $10 \%$ air-filled porosity completely restricted root growth in their experiments. However, if $20 \%$ air-filled porosity was maintained, there was no restriction to root growth due to aeration. A limitation of the LLWR identified by Bengough et al. [33] is the apparent binary nature of thresholds delineated by this technique. Therefore, aeration limits for LLWR can be improved by assuming a linear decline in root growth rate between the water content providing $20 \%$ air-filled porosity of the water content providing $10 \%$ air-filled porosity.

\section{Soil Strength}

Soil strength is a critical factor limiting root penetration of the soil. Soils with high soil strength can prevent roots from exploring soil zones and extracting the water and nutrients required to support plant growth and development. Quantification of soil strength characteristics seldom uses direct measurements of root growth pressure, but rather on rigid, mechanical penetrometer or force gauge measurements. The researcher is then required to relate the penetrometer data to restrictions in root growth. Taylor and Gardner [34] showed that, in a fine sandy loam soil, a penetrometer resistance of greater than $3 \mathrm{MPa}$ prevented cotton (Gossypium hirstum L.) root penetration. There was a linear decline of root penetration as the soil strength increased from 0.9 to $3 \mathrm{MPa}$. Expanding on this finding, Taylor et al. [35] showed that cotton taproot penetration declined rapidly as soil strength increased from 0.3 to $1.5 \mathrm{MPa}$ and taproot penetration was prevented entirely when penetrometer resistance exceeded $2.5 \mathrm{MPa}$. These results were consistent for several coarse and medium textured soils, regardless of soil water matric potential or bulk density. The soil strength limitation on root penetration also seems to be consistent for many species. Taylor and Burnett [36] tested the penetration ability of cotton, sesame (Sesamum indicum L.), guar (Cyamopsis tetragonoloba (L.) Taub.), sesbania (Sesbania exaltata (Raf.) Rydb.), mung bean (Phaseolus aureus Roxb.), cowpea (Vigna sinensis L. var. Chinese Red), and sorghum (Sorghum vulgare Pers. var. Sumac Sorgo). They found that roots from all these species had similar abilities to penetrate compacted soil. Based on these and other studies, the LLWR generally uses a 2-MPa penetrometer resistance as the strength that limits root growth and has a detrimental effect on crop production [18-20].

Whalley et al. [37] devised a relationship between CI, effective stress $\left(\sigma_{\mathrm{w}}\right)$, and bulk density $\left(\rho_{\mathrm{b}}\right)$ as:

$\log _{10} \mathrm{CI}=0.35( \pm 0.009) \log _{10} \sigma_{\mathrm{w}}+0.93( \pm 0.0572) \rho_{\mathrm{b}}+1.2623( \pm 0.0832)$

Effective stress was approximated by $S \psi$, where $S=$ degree of saturation and $\psi=$ pressure potential (in kilopascal).

da Silva and Kay [31] estimated the parameters for the strength function of the LLWR using multiple regression in a similar way as they estimated the water release function. They used multiple regression to determine coefficients based on clay, OC, and logarithmic functions of $\rho_{\mathrm{b}}$ and $\theta$. Their final equation was

$$
\begin{aligned}
\ln \mathrm{CI}=c_{0} & +c_{1} \text { clay }+c_{2} \mathrm{OC}+\left(d_{0}+d_{1} \text { clay }+d_{2} \mathrm{OC}\right) \ln \theta \\
& +\left(e_{0}+e_{1} \text { clay }\right) \ln \rho_{\mathrm{b}}
\end{aligned}
$$

These studies and others document that there is a close relationship between soil strength, bulk density, and water pressure potential. Ideally, this relationship would be measured in the field and effects of different management practices on soil strength would be quantified for each situation. Making such measurements is often impractical. Soil type, soil horizon, tillage practices, and soil compaction level can all affect the soil strength-soil bulk density-soil water pressure potential relationship. With the increased interest in harvesting 
crop residues for bioenergy, bio-products, or simply to reduce subsequent crop residue management problems [6], a simplified method for determining the relationship between SOC and soil strength would be extremely useful for quantifying soil physical effects of this practice.

\section{Testing Pedotransfer Functions}

Predicted $\theta$ and CI were compared with data collected at the Central Great Plains Research Station, near Akron, CO. Water contents at specific soil water matric potentials were taken from a Weld loam reported in Benjamin et al. [10]. Water contents were determined using individual pressure chambers for undisturbed soil cores at $-10 \mathrm{kPa}$ soil water pressure potential and pressure plates at $-1,500 \mathrm{kPa}$ water pressure potential. Soil strength predictions were compared with field measurements of $\theta-\rho_{\mathrm{b}}-\mathrm{CI}$ from a tillage-irrigation-crop rotation study on a Weld loam [13] as well as a slot tillage study on a Rago silt loam (data unpublished). Data for the Weld and Rago soils are presented in Table 1.

\section{Water Content Models}

The pedotransfer functions evaluated in this paper are summarized in Table 2. A test of the Gupta and Larson [24] equations for the Weld loam soil showed a major discrepancy between the water contents predicted and the measured values (data not shown). The predicted wilting point water content was much higher than the measured values for this soil. The predicted field capacity water content was also much greater than those measured. A disturbing difference between the Gupta and Larson [20] predictions and the measured values was the response of the field capacity water content to change in bulk density. The Gupta and Larson [24] prediction showed that water content increased as bulk density decreased. The measured values show that water content decreased as bulk density decreased. Differences in the measured and predicted values can be partially attributed to the differences in soil structure between the remolded cores of the Gupta and Larson [24] study and the undisturbed soil cores from the Akron study. However, the reversal of response of water content to change in bulk density between measurements and predictions leads one to believe that the coefficients used by the Gupta and Larson model may not be suitable for field soils. Further evaluation of this pedotransfer function was abandoned.

Measured water contents at $-1,500 \mathrm{kPa}$ pressure potential agreed closely with the predicted values using the Rawls et al. [25] model (Fig. 2a). Their paper suggested that the coefficient for the response of $\theta$ to $\rho_{\mathrm{b}}$ at both -10 and $-1,500 \mathrm{kPa}$ was zero. The data indicate that $\theta$ increases as $\rho_{\mathrm{b}}$ increases; however, the increase is small. There was a greater discrepancy between predicted and measured $\theta$ at $-10 \mathrm{kPa}$, with nearly $0.1 \mathrm{~m}^{3} \mathrm{~m}^{-3}$ difference over the range of $\theta$ measured.

The measured water contents matched very well with the values predicted by the Ohu et al. [27] (Fig. 2b). The predicted values are close in magnitude to the measured values and the qualitative response of water content to changes in organic matter and bulk density are in the same direction and magnitude as the observations.

The Ritchie et al. [26] model underestimated $\theta$ at both -10 and $-1,500 \mathrm{kPa}$ (Fig. 2c). It is interesting to note that, even though the predicted values of $\theta$ were low in comparison with the measured values, the difference between the two, identified as "plant extractable water," was similar between the measured and predicted values. The Ritchie et al. [26] model may show promise for identifying the $\theta$ limits of the LLWR with calibration for individual soils.

The predicted values of $\theta$ using the coefficients of da Silva and Kay [31] agreed closely with the measured values at both -10 and $-1,500 \mathrm{kPa}$ (Fig. 2d). The model showed a distinct curvilinear response of $\theta$ to both OM and $\rho_{\mathrm{b}}$. Intuitively, a curvilinear response of $\theta$ to $\mathrm{OM}$ is to be expected in that, as OM levels increase, the relative effect on $\theta$ and plant available water would become less.
Table 1 Soil properties used to evaluate pedotransfer functions for water retention and soil strength of Weld loam and Rago silt loam soils and to evaluate SOM effects on the LLWR of a Duroc loam

\begin{tabular}{|c|c|c|c|c|c|c|c|}
\hline Soil & Sand (\%) & Silt (\%) & Clay (\%) & OM (\%) & $\rho_{\mathrm{b}}\left(\mathrm{g} \mathrm{cm}^{-3}\right)$ & LL (vol\%) & $\mathrm{CL}(\mathrm{kPa})$ \\
\hline Weld loam & 31 & 47 & 22 & $\begin{array}{c}\text { Varies } 1.3 \\
\text { to } 1.59\end{array}$ & $\begin{array}{c}\text { Varies } 1.17 \\
\text { to } 1.53\end{array}$ & 25 & 404 \\
\hline Rago silt loam & 42 & 34 & 24 & $\begin{array}{c}\text { Varies } 1.3 \\
\text { to } 3.3\end{array}$ & $\begin{array}{c}\text { Varies } 0.96 \\
\text { to } 1.32\end{array}$ & 25 (est) & 400 \\
\hline \multicolumn{8}{|l|}{ Duroc loam } \\
\hline \multicolumn{8}{|l|}{ Tillage } \\
\hline Sweep & 31 & 44 & 25 & 3.6 & 1.19 & 0.27 & \\
\hline NT & 24 & 44 & 32 & 4.2 & 1.07 & 0.31 & \\
\hline Plow & 38 & 39 & 23 & 2.8 & 1.24 & 0.24 & \\
\hline Sod & 24 & 45 & 31 & 5.3 & 0.95 & 0.36 & \\
\hline
\end{tabular}


Table 2 Regression coefficients for water retention characteristics based on Gupta and Larson [24], Rawls et al. [25], Ritchie et al. [26], Ohu et al. [27], and da Silva and Kay [31]

${ }^{\text {a }}$ Factors for the Gupta and Larson [24] model include particle size distribution (in percent), organic matter (OM, in percent), and bulk density $\left(\rho_{\mathrm{b}}\right.$, in grams per cubic centimeter)

${ }^{\mathrm{b}}$ Additional factors for the $\mathrm{Ohu}$ model include liquid limit (LL, in percent) and compaction level (CL, in kilopascal)

${ }^{c}$ Additional factor for the Seybold model includes cation exchange capacity (CEC, in centimoles per kilogram)

${ }^{\mathrm{d}}$ Additional factor for the da Silva and Kay model includes organic carbon (OC, in percent)

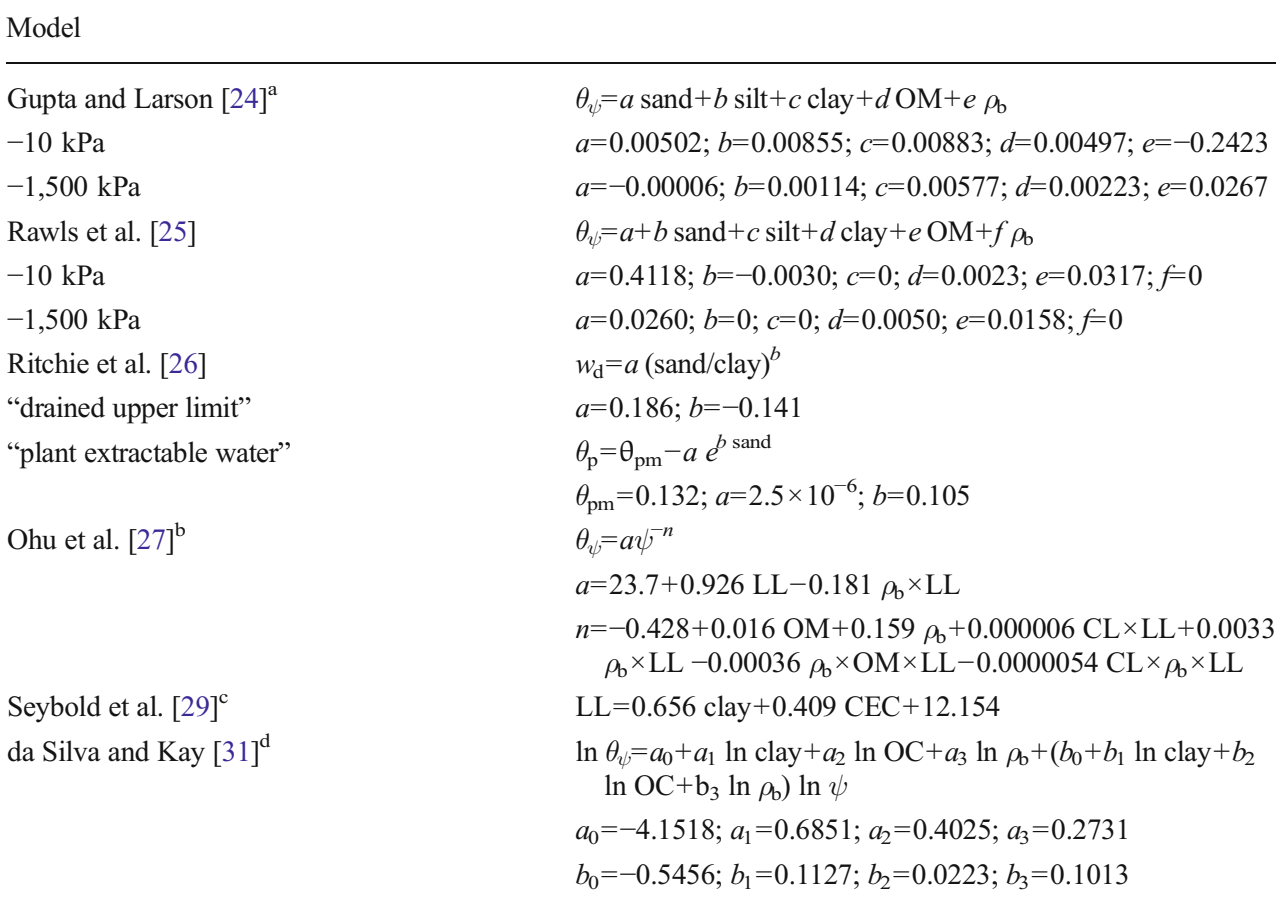

\section{Soil Strength Models}

Using the coefficients shown in Table 3, both the Whalley et al. [37] and da Silva and Kay [31] models gave reasonable estimates of the CI- $\theta-\rho_{\mathrm{b}}$ relationships for the two soils tested (Fig. 3). Both models are highly dependent on accurate estimates of water content. A disadvantage of the Whalley et al. [37] model is the need for accurate estimates of the $\psi-\theta$ relationship, which is not routinely measured for many soil management or cropping system evaluations. The Rawls et al. [25] model estimates $\theta$ at specific $\psi$, but the coefficients are specific for the individual $\psi$. The Ohu et al. [27] model estimates $\psi-\theta$ over a wide range, but is dependent on knowing the LL, another soil property not routinely measured in soil management studies. The advantage of the da Silva and Kay [31] model is its ability to estimate the CI $-\theta-\rho_{\mathrm{b}}$ relationship from routinely measured soil properties of clay content, organic carbon content, and bulk density.

\section{Estimating the LLWR from Basic Soil Properties}

A sensitivity analysis was conducted to evaluate the change of soil organic matter on the LLWR. Two sets of models were used. In the first scenario, the Ohu et al. [27] model was used to estimate the $\psi-\theta$ relationship, and the Whalley et al. [37] model was used to estimate the $\mathrm{CI}-\theta-\rho_{\mathrm{b}}$ relationship. In the second scenario, the equations proposed by da Silva and Kay [31] were used to estimate both the $\psi-\theta$ relationship and the CI $-\theta-\rho_{\mathrm{b}}$ relationship. The particle size data from the Weld loam (Table 1) were used. Estimates for $\psi-\theta$ and $\mathrm{CI}-\theta-\rho_{\mathrm{b}}$ were determined using each method at soil organic matter contents of $10 \mathrm{~g} \mathrm{~kg}^{-1}$ (1 \%) SOM and $50 \mathrm{~g} \mathrm{~kg}^{-1}$ (5\%) SOM. The criteria for the LLWR were (a) $\theta$ which gave $10 \%$ air-filled porosity for aeration limitation; (b) $\theta$ at $-10 \mathrm{kPa} \psi$ for field capacity; (c) $\theta$ at $-1,500 \mathrm{kPa} \psi$ for wilting point; and (d) $\theta$ which gave $2 \mathrm{MPa}$ CI for soil strength limitation, for $\rho_{\mathrm{b}}$ ranging from 0.8 to $1.6 \mathrm{~g} \mathrm{~cm}^{-3}$.

The first scenario using the Ohu et al. [27] and Whalley et al. [37] models was relatively insensitive to changing SOM levels (Fig. 4). The predicted water content at field capacity, wilting point, and the limiting water content for soil strength were slightly higher for $50 \mathrm{~g} \mathrm{~kg}^{-1}$ (5\%) SOM than for $10 \mathrm{~g} \mathrm{~kg}^{-1}(1 \%) \mathrm{SOM}$, but the range between the limiting values was almost the same. These results are not particularly surprising in that the predicted response of $\theta$ to changes in $\mathrm{OM}$ in this range is relatively flat (Fig. 2b). Since the Whalley et al. [37] model depends on the accuracy of predicted $\theta$, there would be little expected change in the predicted strength characteristics if there is little change in predicted $\theta$.

In contrast to scenario 1, using the equations of da Silva and Kay [31] showed a greater change in the LLWR as SOM changed (Fig. 5). The LLWR for the Weld loam with $10 \mathrm{~g} \mathrm{~kg}^{-1}$ (1\%) SOM was predicted to be 0.12 at $1.0 \mathrm{~g} \mathrm{~cm}^{-3} \rho_{\mathrm{b}}$, while the LLWR for the soil with $50 \mathrm{~g} \mathrm{~kg}^{-1}$ (5\%) SOM was predicted to be 0.20 at $1.0 \mathrm{~g} \mathrm{~cm}^{-3} \rho_{\mathrm{b}}$. Another difference is the $\rho_{\mathrm{b}}$ at which the LLWR becomes zero, often called the critical $\rho_{\mathrm{b}}$. For the Weld loam with $10 \mathrm{~g} \mathrm{~kg}^{-1}(1 \%)$ SOM, the critical $\rho_{\mathrm{b}}$ was $1.55 \mathrm{~g} \mathrm{~cm}^{-3}$, while the critical $\rho_{\mathrm{b}}$ for the Weld loam with $50 \mathrm{~g} \mathrm{~kg}^{-1}(5 \%) \mathrm{SOM}$ was $1.36 \mathrm{~g} \mathrm{~cm}^{-3}$. 
Fig. 2 Measured and predicted water retention at -10 and $-1,500 \mathrm{kPa}$ matric potentials for a Weld loam using the models of Rawls et al. [25] (a), Ohu et al. [27] (b), Ritchie et al. [26] (c), and da Silva and Kay [31] (d) a

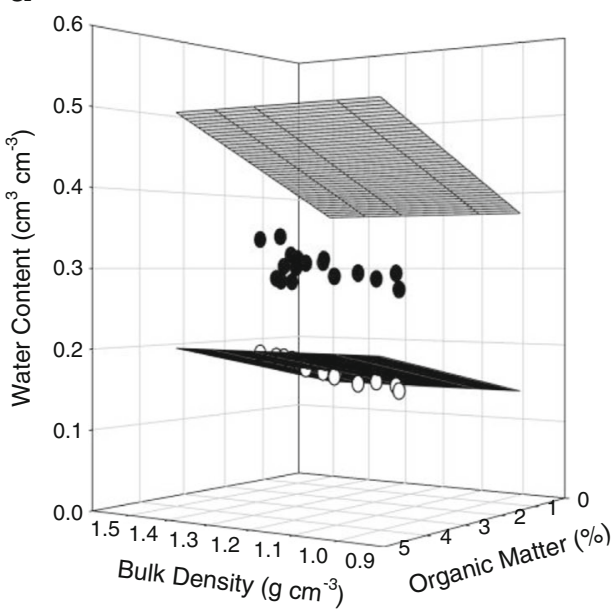

\[ \text { Measured }-10 \mathrm{kPa} \]
$\circ \quad$ Measured $-1500 \mathrm{kPa}$
$\square$ Predicted $-10 \mathrm{kPa}$
$\square$ Predicted $-1500 \mathrm{kPa}$

C

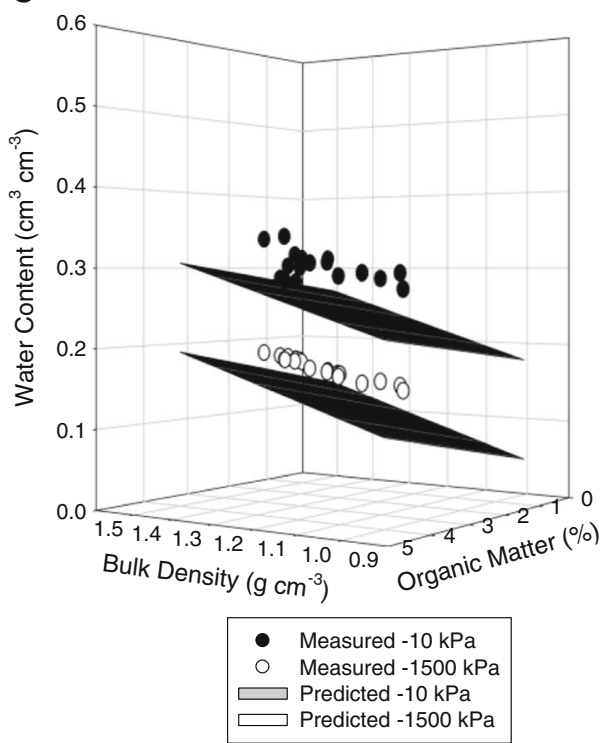

b

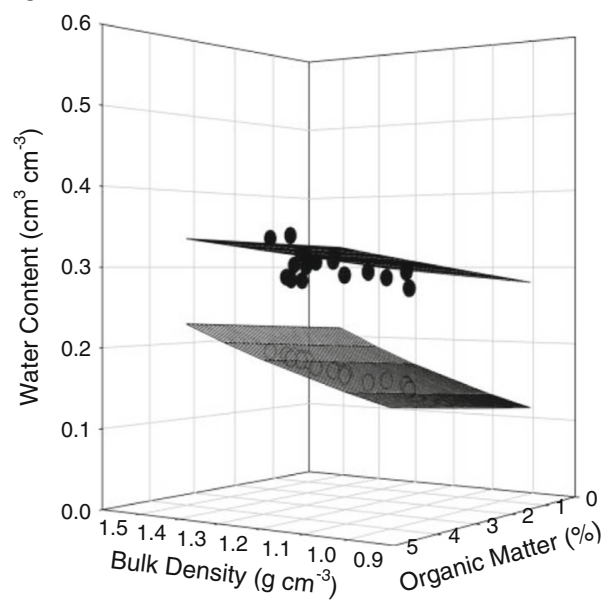

- Measured $-10 \mathrm{kPa}$ Measured $-1500 \mathrm{kPa}$ Predicted $-10 \mathrm{kPa}$ Predicted $-1500 \mathrm{kPa}$

d

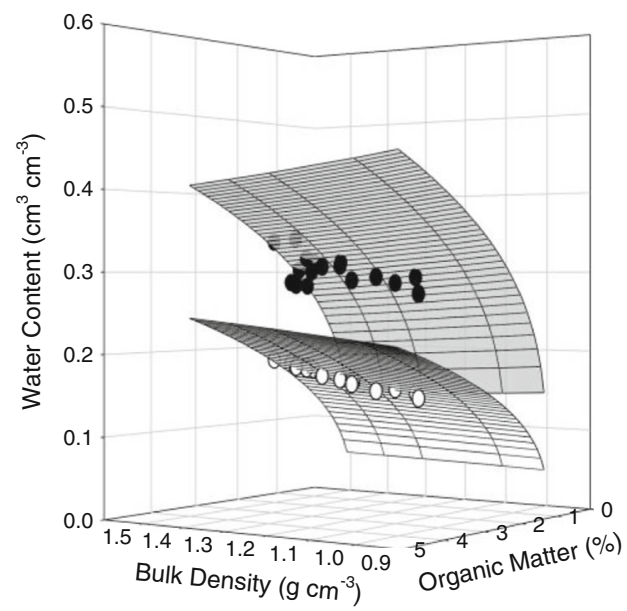

- Measured $-10 \mathrm{kPa}$

- Measured $-1500 \mathrm{kPa}$ $\square$ Predicted $-10 \mathrm{kPa}$
A summary of the effects of changing SOM on the predicted LLWR is shown in Fig. 6. Predictions using the Ohu and Whalley methods indicate little change in the LLWR for loss or gain of SOM (Fig. 6a). The greatest difference in predicted LLWR as SOM increased was at $\rho_{\mathrm{b}}$ of $1.3 \mathrm{~g} \mathrm{~cm}^{-3}$, where the LLWR actually decreased from 0.13 for $0 \mathrm{~g} \mathrm{~kg}^{-1} \mathrm{SOM}$ to 0.11 for $50 \mathrm{~g} \mathrm{~kg}^{-1} \mathrm{SOM}$. The decrease of LLWR as SOM increased is counterintuitive to most observations that soil quality improves as SOM increases. The reason behind this observation is the slight difference in predicted water content as SOM increased, which changed the point at which soil strength, rather than wilting point, became the limiting factor (Fig. 5). The predicted critical $\rho_{\mathrm{b}}$ for all SOM levels was $1.60 \mathrm{~g} \mathrm{~cm}^{-3}$. Predictions of the LLWR using the da Silva and Kay [31] equations indicate an increase in LLWR as SOM increases (Fig. 6b). The relative change of LLWR decreased as SOM level increased between 0 and $50 \mathrm{~g} \mathrm{~kg}^{-1} \mathrm{SOM}$. The critical $\rho_{\mathrm{b}}$ increased from $1.55 \mathrm{~g} \mathrm{~cm}^{-3}$ at $10 \mathrm{~g} \mathrm{~kg}^{-1}$ (1\%) SOM to $1.60 \mathrm{~g} \mathrm{~cm}^{-3}$ at $20 \mathrm{~g} \mathrm{~kg}^{-1}$ (2\%) SOM and then incrementally decreased to $1.35 \mathrm{~g} \mathrm{~cm}^{-3}$ at $50 \mathrm{~g} \mathrm{~kg}^{-1}$ (5\%) SOM.

\section{Practical Applications}

To illustrate the practical applications of using these methods to estimate effects of soil management on the LLWR, data were collected from a Duroc loam near Sidney, NE. The site was in native sod until 1970 when an experiment consisting of 
Table 3 Regression coefficients for CI presented by Whalley et al. [37] and da Silva and Kay [31]

\section{Model}

\begin{tabular}{ll}
\hline Whalley et al. $^{\mathrm{a}} \quad$ & $\log _{10} \mathrm{CI}=a \log _{10} \sigma_{\mathrm{w}}+b \rho_{\mathrm{b}}+c$ \\
& $\sigma_{\mathrm{w}}=S \psi$ \\
& $S=\theta / \theta_{\mathrm{s}}$ \\
& $a=0.35 ; b=0.93 ; c=1.2623$ \\
& $\ln \mathrm{CI}=c_{0}+c_{1}$ clay $+c_{2} \mathrm{OC}+\left(d_{0}+d_{1}\right.$ clay $\left.+d_{2} \mathrm{OC}\right)$ \\
& $\ln \theta+\left(e_{0}+e_{1}\right.$ clay $) \ln \rho_{\mathrm{b}}$ \\
& $c_{0}=-3.6733 ; c_{1}=-0.1447 ; c_{2}=0.7653$ \\
& $d_{0}=-0.4805 ; d_{1}=-0.1239 ; d_{2}=0.208$ \\
& $e_{0}=3.8521 ; e_{1}=0.0963$
\end{tabular}

${ }^{a}$ For the Whalley et al. [37] model, the effective stress $\left(\sigma_{\mathrm{w}}\right)$ is approximated by $S \psi$, where $S$ is the degree of saturation and $\psi$ is the soil water pressure potential. Other parameters for the models include bulk density $\left(\rho_{\mathrm{b}}\right)$, percentage clay (clay), percentage organic carbon $(\mathrm{OC})$, soil water content $\theta$, and saturated water content $\left(\theta_{\mathrm{s}}\right)$

moldboard plow, sweep tillage, no tillage, and continued native sod treatments was imposed [38]. A winter wheatfallow crop rotation was introduced and has been continued to the present. In 2010, soil samples were collected from the $0-15-\mathrm{cm}$ depth and analyzed for $\rho_{\mathrm{b}}$, OM, LL, and particle size analysis. These data were used in the Ohu et al. [27] and Whalley et al. [37] models as well as the da Silva and Kay [31] models to determine tillage effects on the LLWR.

Tillage intensity generally decreased OM, decreased clay content, increased $\rho_{\mathrm{b}}$, and decreased LL (Table 1). As expected, the greatest OM level was found in the sod plots and the lowest was in the moldboard plow plots. The sod and NT plots had similar clay contents, but the sweep tillage and moldboard plow plots had lower clay contents, possibly due to erosion over the last 40 years. Sod plots had the lowest $\rho_{\mathrm{b}}$ and moldboard plow plots had the greatest $\rho_{\mathrm{b}}$. Differences in SOM and clay content were reflected by changes in the LL among the various treatments. The sod plots had the greatest LL, moldboard the lowest, and the others had intermediate LL values.

Differences in basic soil properties were also reflected in the predicted LLWR values among tillage
Fig. 3 Predicted bulk density $\left(\rho_{\mathrm{b}}\right)$-volumetric water content $\left(\theta_{\mathrm{v}}\right)$-cone index $(\mathrm{CI})$ relationships. Subpanels a and $\mathbf{b}$ denote measured and predicted values from an in-row slot tillage study with measurements from within the tilled slot and between rows based on Whalley et al. [37] and da Silva and Kay [31] models, respectively. Subpanels c and $\mathbf{d}$ denote measured and predicted values from a chisel plow study with measurements from tilled and no-till plots based on Whalley et al. [37] and da Silva and Kay [31] models, respectively a

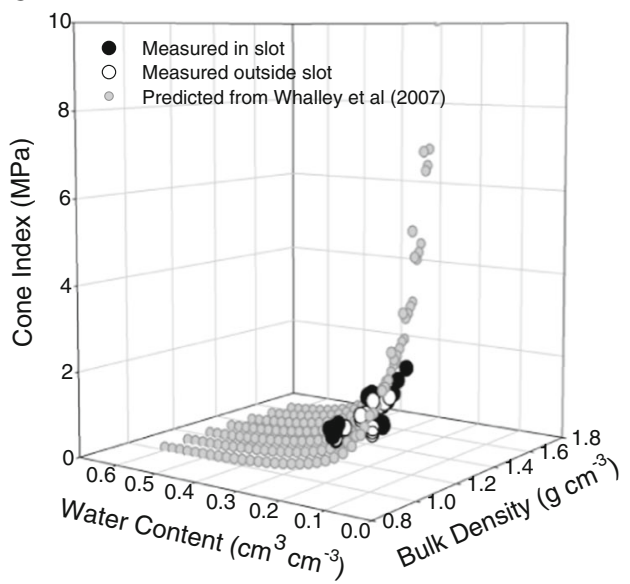

C

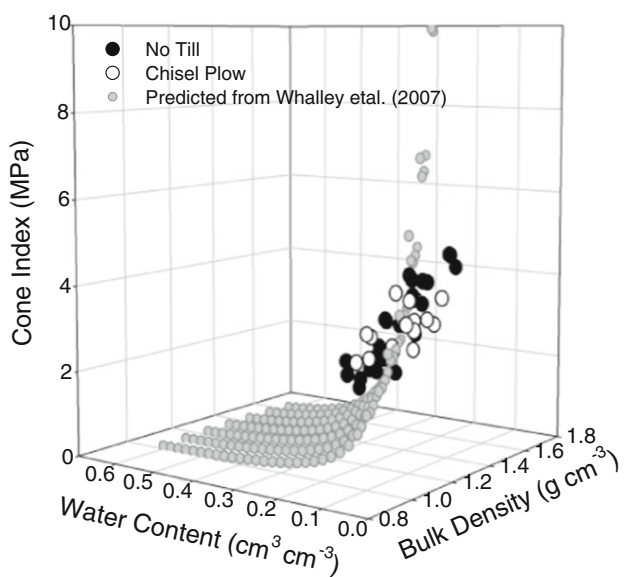

b

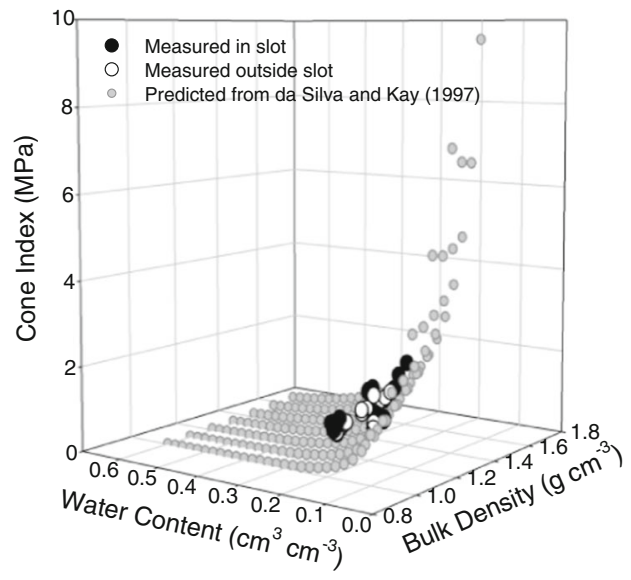

d

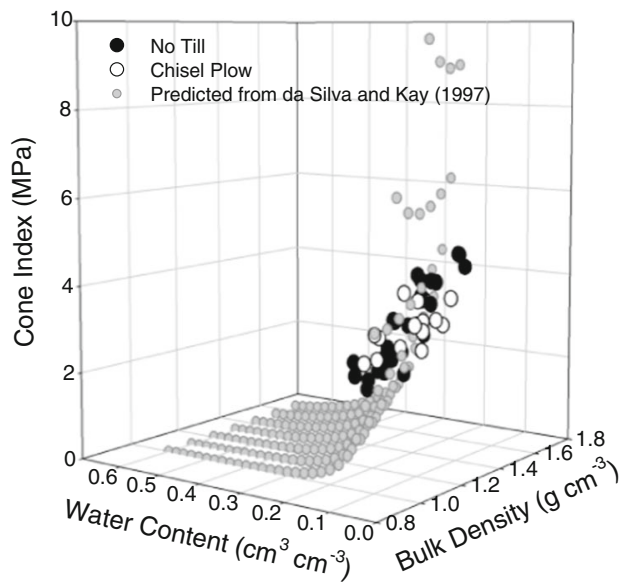


Fig. 4 Predicted SOM effects on LLWR for a Weld loam with either $10 \mathrm{~g} \mathrm{~kg}^{-1}$ (1\%) SOM (A) or $50 \mathrm{~g} \mathrm{~kg}^{-1}$ (5\%) SOM (B) using the Ohu et al. [27] and Whalley et al. [37] equations
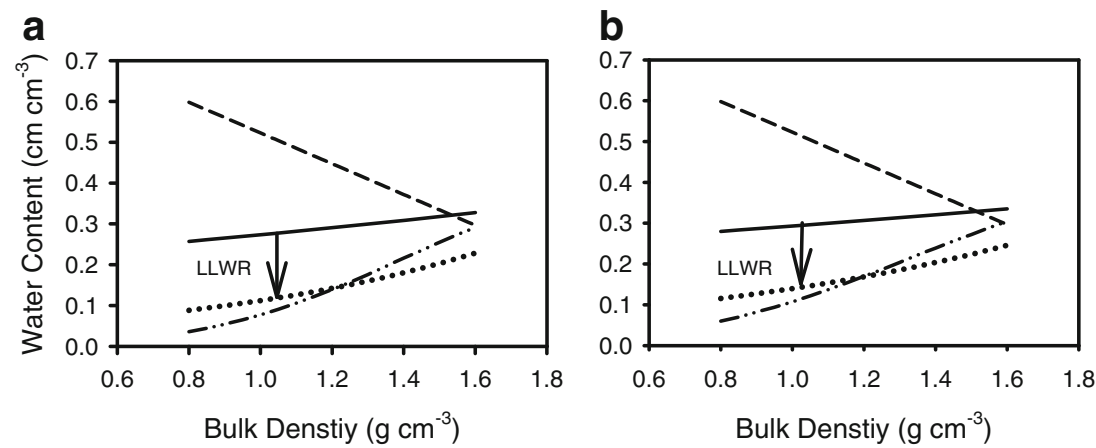

treatments (Fig. 7). The first scenario, using the Ohu et al. [27] and Whalley et al. [37] models (Fig. 7a), indicates that the sod treatment has a better soil physical condition than the cropped treatments. Factors contributing to this included lower $\rho_{\mathrm{b}}$ in the sod treatment than in the tilled treatments which had increasing physical problems as $\rho_{\mathrm{b}}$ increased. The predicted LLWR for sod at $1.0 \mathrm{~g} \mathrm{~cm}^{-3} \rho_{\mathrm{b}}$ was 0.18 compared with 0.17 for NT, 0.164 for sweep tillage, and 0.158 for moldboard plow. The LLWR predictions were essentially the same at $1.22 \mathrm{~g} \mathrm{~cm}^{-3} \rho_{\mathrm{b}}$. At greater $\rho_{\mathrm{b}}$, the LLWR prediction for the sod was less than the tilled treatments. The critical $\rho_{\mathrm{b}}$ increased with tillage intensity. The critical $\rho_{\mathrm{b}}$ for the sod plots was $1.47 \mathrm{~g} \mathrm{~cm}^{-3}$ and the critical $\rho_{\mathrm{b}}$ for the moldboard plow plots was $1.6 \mathrm{~g} \mathrm{~cm}^{-3}$. Combining the predicted LLWR response curves with the observed field $\rho_{\mathrm{b}}$ shows the LLWR for the sod plots was 0.18 , the LLWR for the NT plots was 0.16, the LLWR for the sweep tillage plots was 0.14 , and the LLWR for the moldboard plow plots was 0.13 .
The equations of da Silva and Kay [31] also indicate that the sod has a better soil physical condition than the cropped treatments at low $\rho_{\mathrm{b}}$ and worse soil physical condition at high $\rho_{\mathrm{b}}$ (Fig. 7b). The predicted LLWR for sod at $1.0 \mathrm{~g} \mathrm{~cm}^{-3} \rho_{\mathrm{b}}$ was 0.22 compared with 0.20 for NT, 0.19 for sweep tillage, and 0.17 for moldboard plow. At $1.5 \mathrm{~g} \mathrm{~cm}^{-3} \rho_{\mathrm{b}}$, the LLWR for the sod plots was 0 compared with 0.02 for NT plots, 0.03 for sweep tillage plots, and 0.02 for moldboard plow plots. These equations also showed that the critical $\rho_{\mathrm{b}}$ increased with tillage intensity. The critical $\rho_{\mathrm{b}}$ for the sod plots was $1.50 \mathrm{~g} \mathrm{~cm}^{-3}$, the critical $\rho_{\mathrm{b}}$ for the NT plots was $1.55 \mathrm{~g} \mathrm{~cm}^{-3}$, the critical $\rho_{\mathrm{b}}$ for the sweep tillage plots was $1.6 \mathrm{~g} \mathrm{~cm}^{-3}$, and the critical $\rho_{\mathrm{b}}$ for the moldboard plow plots was $1.6 \mathrm{~g} \mathrm{~cm}^{-3}$. Combining the predicted LLWR response curves with the observed field $\rho_{\mathrm{b}}$ using this scenario shows the LLWR for the sod plots was 0.24 , the LLWR for the NT plots was 0.18, the LLWR for the sweep tillage plots was 0.13 , and the LLWR for the moldboard plow plots was 0.10 .

Based on these tillage and cropping system studies, we project that LLWR assessments could be very useful
Fig. 5 Predicted LLWR for a Weld loam with $10 \mathrm{~g} \mathrm{~kg}^{-1}(1 \%)$ $\mathrm{SOM}$ (a) or $50 \mathrm{~g} \mathrm{~kg}^{-1}(5 \%) \mathrm{SOM}$ (b) using the da Silva and Kay [31] equations
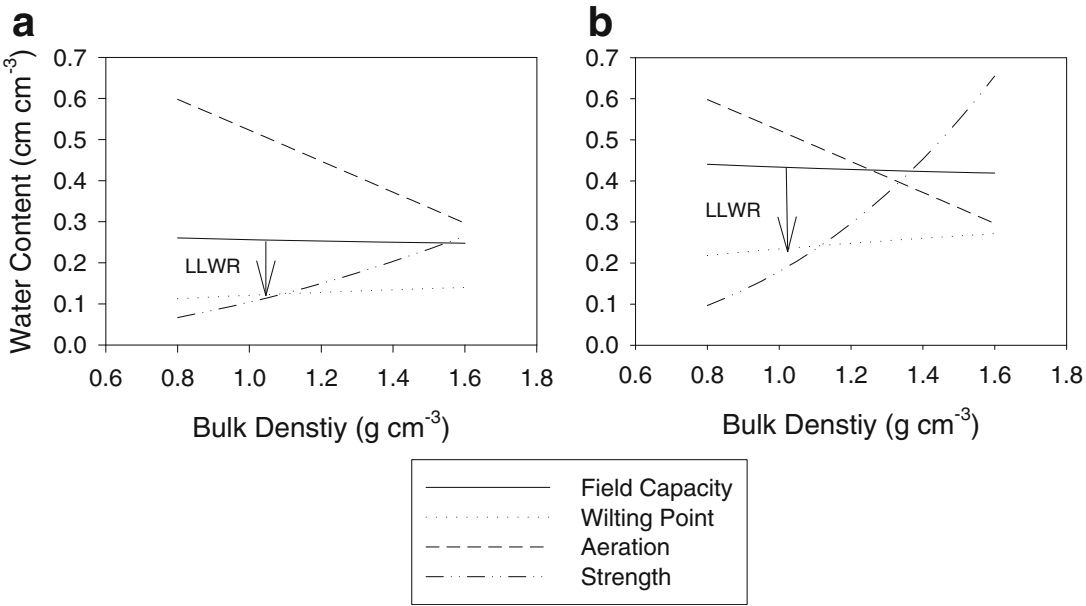
a

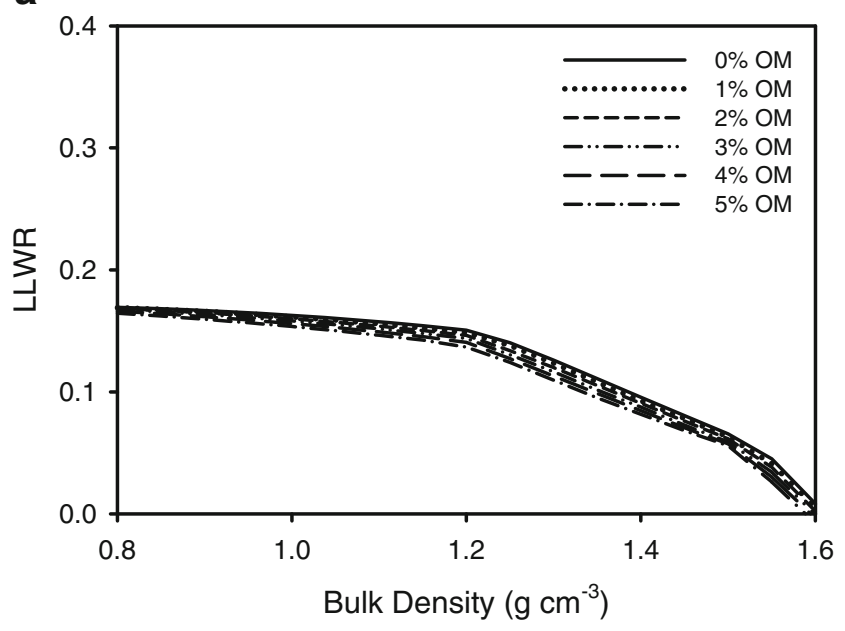

b

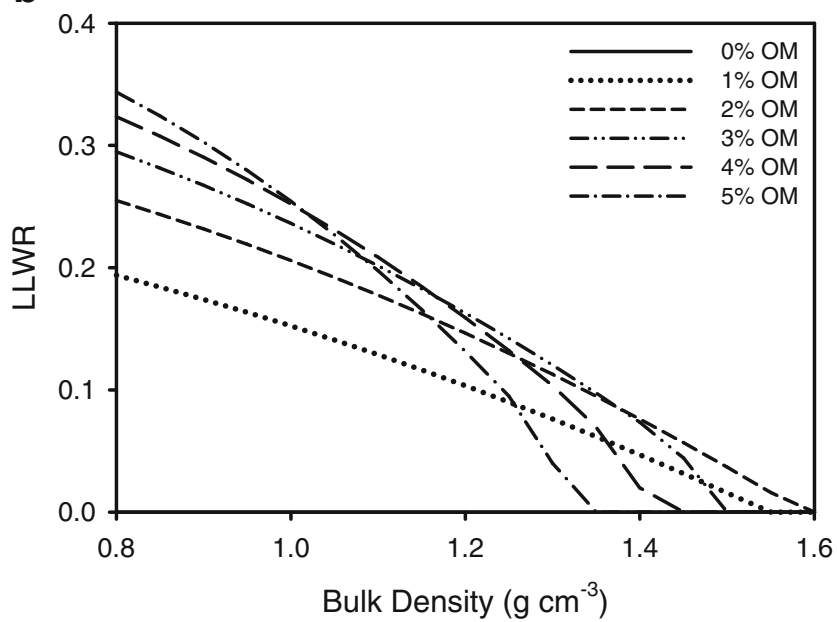

Fig. 6 Comparisons of predicted LLWR for a Weld loam based on the Ohu et al. [27] and Whalley et al. [37] equations (a) or the da Silva and Kay [31] equations (b) with SOM from 10 to $50 \mathrm{~g} \mathrm{~kg}^{-1}$ (1 to $5 \%$ ). Note: the LLWR for $0 \% \mathrm{SOM}$ in B is not apparent because the value is zero for all $\rho_{\mathrm{b}}$

for assessing potential soil compaction impacts if ecosystem service effects are ignored and too much crop residue is harvested for bioenergy or bio-products. Several methods for estimating the LLWR have been illustrated and are shown to give similar information when applied to long-term field studies. The difficulty in directly monitoring soil compaction effects due to stover harvest leads us to conclude that estimating the LLWR and monitoring it over time is currently the best approach for addressing this critical problem.

\section{Summary}

Devising soil management systems that maintain or improve SOC levels is crucial for long-term sustainability and a

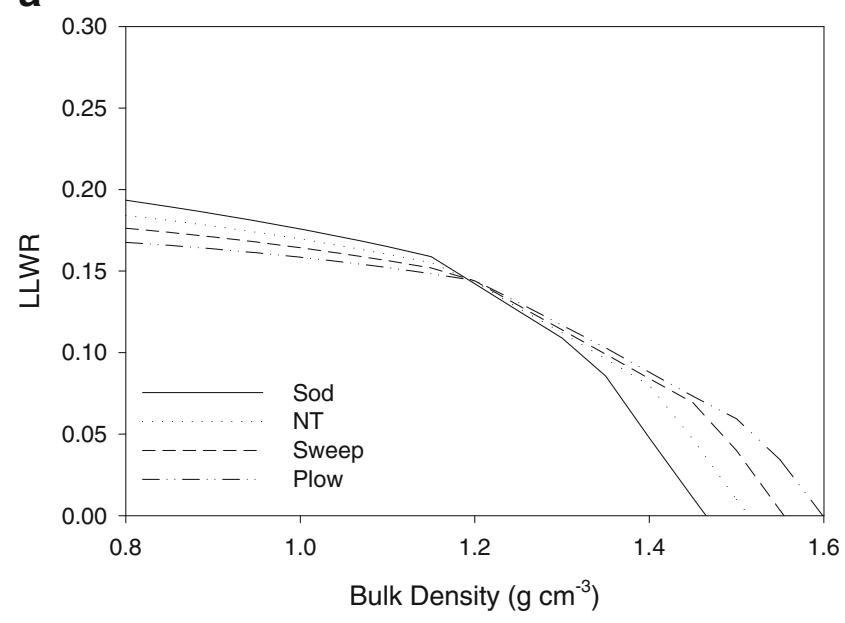

b

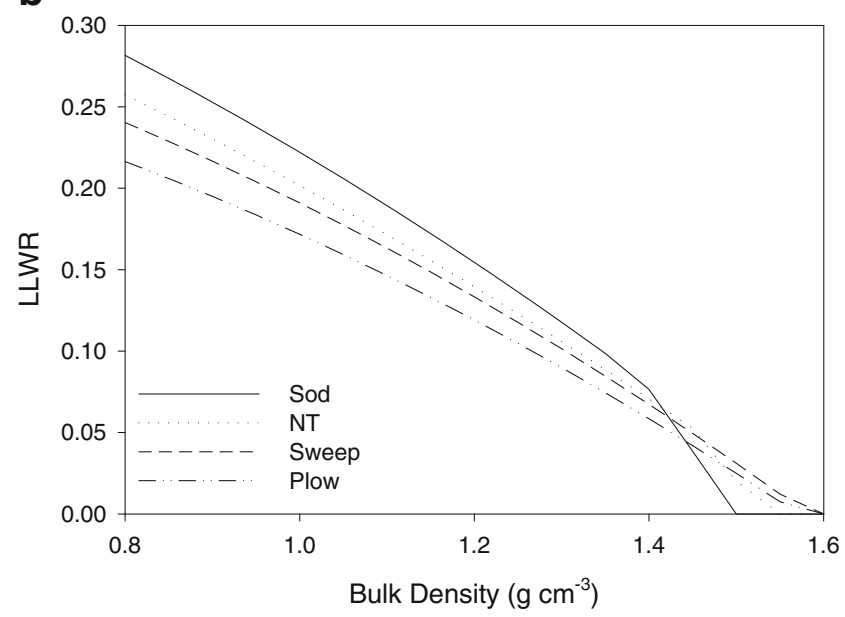

Fig. 7 Tillage effects on predicted LLWR of a Duroc loam. Figure a shows the estimates of LLWR using the Ohu et al. [27] for water content and the Whalley et al. [37] model for soil strength. Figure b shows the estimates of LLWR using the da Silva and Kay [31] model for both water content and soil strength. Changes in soil parameters caused by tillage are shown in Table 3

productivity. As SOC levels increase, physical properties such as soil strength, water holding capacity, and resistance to compaction by wheel traffic become less limiting to plant growth and development. Decreasing SOC levels have been shown to impair soil physical conditions, as defined by the LLWR. Furthermore, the effects that SOC changes on the LLWR are more pronounced on soils with inherently low SOC levels. However, as SOC levels increase, soil physical properties are also improved. Therefore, for maintenance of optimum soil physical properties and processes, we recommend that decisions to harvest crop residue for any purpose be site specific and focused on maintaining or enhancing the existing SOC content.

Finally, this paper enumerates several options for the evaluation of changing SOC levels on soil physical quality and 
potential changes in soil productivity. Of those methods, the equations originally presented by da Silva and Kay [31] appear to be very useful for evaluating SOC changes on soil physical quality. Using this LLWR method in conjunction with routine documentation of $\rho_{\mathrm{b}}$ changes will provide a solid foundation for evaluating the overall effects of harvesting crop residue for any type of bioenergy or bio-product production.

Acknowledgments The U.S. Department of Agriculture offers its programs to all eligible persons regardless of race, color, age, sex, or national origin, and is an equal-opportunity employer.

This study was funded by the USDA-Agricultural Research Service as part of the USDA-ARS-Resilient Economic Agricultural Practices project with additional funds from the North Central Regional Sun Grant Center at South Dakota State University through a grant provided by the US Department of Energy - Office of Biomass Programs under award number DE-FC36-05GO85041.

\section{References}

1. National Academy of Sciences (NAS) (2009) Liquid transportation fuels form coal and biomass: technological status, costs, and environmental impacts. The National Academies Press, Washington, D.C., p 322

2. U.S. Department of Energy (2011) U.S. billion-ton update: biomass supply for a bioenergy and bioproducts industry. R.D. Perlack and B.J. Stokes (Leads), ORNL/TM-2011/224. Oak Ridge National Laboratory, Oak Ridge, TN. 227 p.

3. Tilman D, Socolow R, Foley JA, Hill J, Larson E, Lynd L, Pacala S, Reilly J, Searchinger T, Somerville C, Williams R (2009) Beneficial biofuels - the food, energy, and environment trilemma. Science 325: 270-271

4. Kim S, Dale BE (2004) Global potential bioethanol production from wasted crops and crop residues. Biomass Bioenergy 26:361-375

5. Lal R (2009) Soil quality impacts of residue removal for bioethanol production. Soil Tillage Res 102:233-241

6. Wilhelm WW, Hess JR, Karlen DL, Johnson JMF, Muth DJ, Baker JM, Gollany HT, Novak JM, Stott DE, Varvel GE (2010) Review: balancing limiting factors and economic drivers for sustainable midwestern US agricultural residue feedstock supplies. Ind Biotechnol 6: 271-287

7. Blanco-Canqui H, Lal R (2008) Corn stover removal impacts on micro-scale soil physical properties. Geoderma 145:335-346

8. Bauer A, Black AL (1981) Soil carbon, nitrogen, and bulk density comparisons in two cropland tillage systems after 25 years and in virgin grassland. Soil Sci Soc Am J 45:1166-1170

9. Christopher SF, Lal R, Mishra U (2009) Regional study of no-till effects on carbon sequestration in the Midwest United States. Soil Sci Soc Am J 73:207-216

10. Benjamin JG, Mikha MM, Vigil MF (2008) Organic carbon effects on soil physical and hydraulic properties in a semi-arid climate. Soil Sci Soc Am J 72:1357-1362

11. Follett RF, Jantalia CP, Halvorson AD (2013) Soil carbon dynamics for irrigated corn under two tillage systems. Soil Sci Soc Am J 77: 951-963
12. Linden DR, Clapp CE, Dowdy RH (2000) Long-term corn grain and stover yields as a function of tillage and residue removal in east central Minnesota. Soil Tillage Res 56:167-174

13. Benjamin JG, Halvorson AD, Nielsen DC, Mikha MM (2010) Crop management effects on crop residue production and changes in organic carbon in the central Great Plains. Agron J 102:990-997

14. Wilhelm WW, Johnson JMF, Karlen DL, Lightle DT (2007) Corn stover to sustain soil organic carbon further constrains biomass supply. Agron J 99:1665-1667

15. Larson WE, Clapp CE, Pierre WH, Morachan YB (1972) Effects of increasing amounts of organic residues on continuous corn: II. Organic carbon, nitrogen, phosphorus, and sulfur. Agron J 64:204-208

16. Pikul JL Jr, Johnson JMF, Schumacher TE, Vigil M, Riedell WE (2008) Change in surface soil carbon under rotated corn in eastern South Dakota. Soil Sci Soc Am J 72:1738-1744

17. Soane BD (1990) The role of organic matter in soil compactibility: a review of some practical aspects. Soil Tillage Res 16:179-201

18. Letey J (1985) Relationship between soil physical properties and crop production. Adv Soil Sci 1:277-294

19. da Silva AP, Kay BD, Perfect E (1994) Characterization of the least limiting water range of soils. Soil Sci Soc Am J 58:1775-1781

20. Benjamin JG, Nielsen DC, Vigil MF (2003) Quantifying effects of soil conditions on plant growth and crop production. Geoderma 116: 137-148

21. Betz CL, Allmaras RR, Copeland SM, Randall GW (1998) Least limiting water range: traffic and long-term tillage influences in a Webster soil. Soil Sci Soc Am J 62:1384-1393

22. Bouma J, van Lanen HAJ (1987) Transfer functions and threshold values from soil characteristics to land qualities. In: Quantified land evaluation, Proc Workshop ISSS/SSSA, Washington, DC. ITC Publ., Enschede, the Netherlands. pp 106-111

23. Wagenet RJ, Bouma J, Grossman RB (1991) Minimum data sets for use of soil survey information in soil interpretive models. In: Mausbach MJ, Wilding LP (eds) Spatial variabilities of soil and landforms. SSSA, Madison, pp 161-182, SSSA Spec Publ 28

24. Gupta SC, Larson WE (1979) Estimating soil water retention characteristics from particle size distribution, organic matter percent, and bulk density. Water Resour Res 15:1633-1635

25. Rawls WJ, Brakensiek DL, Saxton KE (1982) Estimation of soil water properties. Trans ASAE 25:1316-1328

26. Ritchie JT, Gerakis A, Suleiman A (1999) Simple model to estimate field-measured soil water limits. Trans ASAE 42:1609-1614

27. Ohu JO, Raghavan GSV, Prasher S, Mehuys G (1987) Prediction of water retention characteristics from soil compaction data and organic matter content. J Agric Eng Res 38:27-35

28. McBride RA (2002) Atterberg limits. In: Dane JH, Topp GC (eds) Methods of soil analysis. Part 4. Physical methods. Soil Science Society of America, Madison, pp 389-398, Soil Science Society of America Book Series Number 5

29. Seybold CA, Elrashidi MA, Engel RJ (2008) Linear regression models to estimate soil liquid limit and plasticity index from basic soil properties. Soil Sci 173:25-34

30. De Jong E, Acton DF, Stonehouse HB (1990) Estimating the Atterberg limits of Southern Saskatchewan soils from texture and carbon contents. Can J Soil Sci 70:543-554

31. da Silva AP, Kay BD (1997) Estimating the least limiting water range of soils from properties and management. Soil Sci Soc Am J 61:877-833

32. Grable AR, Siemer EG (1968) Effects of bulk density, aggregate size, and soil water suction on oxygen diffusion, redox potentials, and elongation of corn roots. Soil Sci Soc Am Proc 32:180-186

33. Bengough AG, Bransby MF, Hans J, McKenna SJ, Roberts TJ, Valentine TA (2006) Root responses to soil physical 
conditions; growth dynamics from field to cell. J Exp Bot 57: 437-447

34. Taylor HM, Gardner HR (1963) Penetration of cotton seedling taproots as influenced by bulk density, moisture content, and strength of soil. Soil Sci 96:153-156

35. Taylor HM, Roberson GM, Parker JJ Jr (1966) Soil strength-root penetration relations for medium- to coarse-textured soil materials. Soil Sci 102:18-22
36. Taylor HM, Burnett E (1964) Influence of soil strength on rootgrowth habits of plants. Soil Sci 98:174-180

37. Whalley WR, To J, Kay BD, Whitmore AP (2007) Prediction of the penetrometer resistance of soils with models with few parameters. Geoderma 137:370-377

38. Mielke LN, Wilhelm WW (1998) Comparisons of soil physical characteristics in long-term tillage winter wheat-fallow tillage experiments. Soil Tillage Res 49:29-35 